\title{
KAZIMIERZ PÓŁTORAK \\ Rola parafii w duszpasterstwie młodzieży. Kierunki odnowy w warunkach przemian
}

Podczas niezapomnianego spotkania z młodymi podczas XV Światowego Dnia Młodzieży w Rzymie papież Jan Paweł II wezwał wspólnoty chrześcijańskie, środowiska młodzieżowe, aby umiały stwarzać dla młodych warunki życia, które nazwal prawdziwymi laboratoriami wiary'. W takich środowiskach młodzież miałaby możliwość wzrostu w wierze, umacniania się w życiu duchowym, uczenia się sposobów świadczenia Dobrej Nowinie Jezusa Chrystusa we współczesnym świecie. Wezwanie to dotyczy także współczesnych parafii polskich, które po przeniesieniu katechizacji do szkól przeżywają wieloaspektowe trudności w realizacji duszpasterstwa mlodzieży adekwatnego do aktualnych potrzeb. Czy współczesne parafie realizują papieski postulat? W jaki sposób młodzi ludzie mogą w parafii i przez parafię wzrastać w życiu chrześcijańskim?

\section{Młodziėz, parafia, duszpasterstwo młodzieży}

Mówiąc o młodzieży można mieć na myśli różne aspekty tej kondycji życia. Młodzież to określona grupa wiekowa, to określona kultura życia, a raczej subkultura, można tak nazwać również w pewnym sensie określony status społeczny, pewien typ klasy społecznej. Młodość wyznacza określony sposób percepcji świata, specyficzne oczekiwania, nadzieje, pewnego rodzaju twórczość ducho-

${ }^{1} \mathrm{~J}$ a n P awe 1 I I: Nie lękajcie się zawierzyć Chrystusowi. Przemówienie wygloszone podczas czuwania modlitewnego w Tor Vergata. „L'Osservatore Romano”. Wydanie polskie. R. 21: 2000 nr 10 s. 19. 
wą, dynamiczny typ myślenia. Należy postrzegać mlodość w całościowym procesie dojrzewania czlowieka od dzieciństwa, przez dorastanie, młodzieńczość wczesną oraz późna, do dorosłości, dojrzałości życiowej i starości. W zależności od sposobu ujęcia zagadnienia mlodości czlowieka, mówić można o mlodzieży gimnazjalnej, licealnej, studenckiej, pracującej, o młodych małżeństwach, młodzieży pracującej itd. Przedmiotem zainteresowania niniejszego opracowania jest młodzież szkól średnich i problemy duszpasterskie dotyczące osób pomiędzy ostatnią klasą gimnazjum, a okresem maturalnym.

Specyfika duszpasterstwa tej grupy młodzieży wiąże się z przejściem do nowych środowisk związanych ze zmianą szkoły. Ma to wpływ na nowy sposób relacji ze środowiskiem własnej parafii. Duszpasterze zauważaja, że poszczególne osoby gdzieś „zginęły” z parafii po przejściu do szkoły średniej. Spostrzeżenie to ukazuje frustrację proboszczów, wikariuszy, prefektów przywiązanych do tradycyjnego rozumienia duszpasterstwa oraz roli parafii, w której duszpasterzu$\mathrm{ja}^{2}$. Takie podejście prezentują również różne agendy diecezjalne: mówi się o parafialnych rekolekcjach młodzieżowych, statystykach duszpasterstwa młodzieży w parafii itp. W powszechnym rozumieniu bowiem, duszpasterstwo młodzieży to rodzaj duszpasterstwa stanowego, propozycje modlitewno-formacyjne kierowane przez parafię do młodzieży szkolnej. Tymczasem podstawy biblijnoteologiczne wskazują na potrzebę szerszego rozumienia tej galęzi duszpasterstwa.

W ujęciu starotestamentalnym troska o młodego człowieka w głównej mierze ma na celu nauczenie go uleglości Bogu, jedynemu Wychowawcy przez cnotę mądrości i posłuszeństwa. Metoda jest zrozumienie, karność i upomnienie stosowane przez wychowawców, głównie rodziców. To wlaśnie rodzina jako wspólnota ma największą możliwość formowania młodego czlowieka, to $\mathrm{w}$ atmosferze tej pierwotnej wspólnoty życia młody człowiek może nauczyć się mądrości i dostrzec zatroskanie Boga o czlowieka. Nowy Testament ukazuje życie człowieka w perspektywie boskiego panowania Chrystusa Zmartwychwstałego. Troska o młodzież ma być więc wspieraniem jej w dojrzewaniu duchowym w perspektywie eschatologicznej. Naturalnym, uwznioślonym przez Chrystusa środowiskiem dojrzewania człowieka jest rodzina. Chrystus nadał środowisku rodzinnemu walor świętości, a jej osiaganie to służba Bogu przez wzajemną

${ }^{2}$ T. P a n u ś: Parafia uprzywilejowanym miejscem dla katechezy przygotowujacej do sakramentów inicjacji chrześcijańskiej. „Zeszyty Katechetyczne”. R. 3: $2003 \mathrm{nr} 30 \mathrm{s.} 144$; por. S. H. $\mathrm{Z}$ a r ę b a: Współczesne uwarunkowania religijnego wychowania w Polsce. W: Wychowanie religijne u progu trzeciego tysiqclecia chrześcijaństwa. Red. R. C h a 1 u p n i a k, J. K o s t o r z. Opole 2001 s. 122n; J. S z p e t: Podstawa programowa katechezy Kościoła katolickiego W: tamże, s. 185. 
miłość rodziców i dzieci ${ }^{3}$. Kościól wypełniając posłannictwo Chrystusa, zadanie wychowania traktuje jako swoja podstawowa misję. W praktyce realizuja to zadanie rozliczne podmioty życia Kościola dopomagając dzieciom i młodzieży $w$ harmonijnym rozwoju wrodzonych właściwości fizycznych, moralnych i intelektualnych, do zdobywania coraz doskonalszego zmysłu odpowiedzialności w należytym kształtowaniu własnego życia przez nieustanny wysiłek w osiqganiu prawdziwej wolności (DWCH 1). Wychowanie lączy się ściśle z duszpasterstwem młodzieży, nie można więc wyobrazić sobie duszpasterstwa młodzieży bez udziału rodziny, szkoły, parafii, środowisk kulturalnych, sportowych, coraz większych obszarów rozrywki, muzyki i rekreacji.

Początki tworzenia struktur duszpasterstwa młodzieży w Polsce można odnaleźć w latach dwudziestych minionego stulecia, gdy rozpowszechnioną formą pastoralnego oddziaływania Kościoła było duszpasterstwo stanowe, różnicujące grupy głównie ze względu na wiek i płeć. Podział ten zyskał na znaczeniu od czasu utworzenia w 1943 r. czterech kolumn Akcji Katolickiej: kobiety, mężczyźni, młodzież żeńska i męska. Po II wojnie światowej panujący system totalitarny w znacznym stopniu ograniczyl zakres duszpasterstwa młodzieży, które funkcjonowało $\mathrm{w}$ takim wymiarze i zakresie, jaki dawaly sale parafialne, punkty katechetyczne i plebanie ${ }^{4}$. Mimo zakazów i restrykcji ze strony władz państwowych powstawaly nowe inicjatywy duszpasterstwa młodzieży: duszpasterstwo harcerzy, akademickie, młodzieży pracującej, pielgrzymkowe, oazowe, itd. ${ }^{5}$.

W latach siedemdziesiąych zaczęły powstawać grupy i ruchy religijne $\mathrm{z}$ udziałem młodych, organizowano festiwale piosenki religijnej, konkursy chórów, recytatorskie, diecezjalne pielgrzymki do sanktuariów, całonocne czuwania. Rozwijaly się krajowe i diecezjalne struktury duszpasterstwa młodzieży, przez które rozumiano wszelkie inicjatywy pastoralne poza systematyczną katechizacją $^{6}$. Wzrost procesów wolnościowych w latach osiemdziesiątych wplyną na ożywienie aktywności młodzieżowych środowisk, również kościelnych. Mocno rozwiną się w tym czasie ruch oazowy, znacznej popularności nabrały obchody dni młodzieży, wzrosło zainteresowanie młodych działalnością grup kościelnych. Jak dla całego życia kościelnego w Polsce, tak i dla duszpasterstwa młodzieży, wymiar religijno-narodowy polskiego katolicyzmu w sposób naturalny sprzyjal akcentowaniu priorytetu parafii. To dzięki silnemu oddziaływaniu struktur para-

${ }^{3}$ M. Ka li n ow ski: Duszpasterstwo młodzieży. W: Duszpasterstwo specjalne. Red. R. Ka m i ń s ki, B. D r ożd ż. Lublin 1998 s. 22n.

${ }^{4}$ Zob. A. R y n i o: Wychowanie młodzicży w nauczaniu Kardynala Stefana Wyszynskiego. Lublin 1995 s. 25-38.

${ }^{5}$ K. Pawlina: Modzież i jej duszpasterze w czasach zniewolenia. Warszawa 1993 s. $110 \mathrm{nn}$.

${ }^{6}$ Zob. M. Ka 1 i n ow s k i, dz. cyt., s. 28. 
fialnych, jej społecznemu autorytetowi, inicjatywy duszpasterstwa młodzieży byly skuteczne.

Proces demokratyzacji życia lat dziewięćdziesiąych, wejście społeczeństwa na drogę zmian strukturalnych i kulturowych, znacznie skomplikowaly skuteczność propozycji duszpasterstwa młodzieży. Duszpasterze z roku na rok odnotowywali ociężalość tego duszpasterstwa, pojawiały się oskarżenia księży o słabe umiejętności pedagogiczne, brak kontaktu z mlodzieżą, szukało się winnych nikłych efektów poszczególnych inicjatyw pastoralnych. Obecnie nadal można mówić o tradycyjnych kierunkach animowania duszpasterstwa młodzieży wszelka działalność opiera się na parafii i jej inicjatywach. Jeżeli nawet inspiracją są agendy kurii biskupiej, to i tak realizacją obciąża się parafie i księży tam pracujących. Duszpasterze nie potrafią znaleźć wyjścia z patowej sytuacji: podejmują wysiłki, coraz to nowe inicjatywy, a efekty zupełnie nie odpowiadaja oczekiwaniom. Odpowiedzialni i planiści oskarżają młodych księży o brak skuteczności, duszpasterze pracujący w szkołach i parafiach widząc wlasny wysilek winą za nieefektywność obarczają planistów i strategów duszpasterstwa za brak pomysłu „na pracę z młodzieżą"7. Sytuacja taka budzi rozdźwięk między proboszczami a ich współpracownikami, między odpowiedzialnymi za duszpasterstwo a kapłanami pracującymi w parafiach. Pozostaje jednak faktem, że duszpasterstwo młodzieży przeżywa trudny okres „odnalezienia się” w nowych warunkach. Najważniejsze jest zaś to, że rzeczywiście młodzież ma słaby kontakt z parafią i jej propozycjami duszpasterskimi ${ }^{8}$.

\section{Nowe potrzeby duszpasterskie i oczekiwania młodzieży wobec parafii}

Zmieniająca się rzeczywistość społeczno-kulturowa z roku na rok kształtuje nowy typ osobowości młodych ludzi. Zmienia się jej sposób postrzegania świata, preferowane wartości, a także religijność. Na rozwój religijności młodych maja wpływ już nie tylko tradycyjne instytucje socjalizacyjne, tj. rodzina czy Kościól, ale coraz bardziej mass media, szkoła i grupy rówieśnicze. Wraz z pluralizowaniem się nowoczesnego społeczeństwa wszyscy, a szczególnie mlodzi,

\footnotetext{
${ }^{7}$ Są to głosy księży pracujących na różnych szczeblach duszpasterstwa zebrane przez autora podczas różnorodnych spotkań formalnych i nieformalnych.

${ }^{8}$ K. N y c z: Działalność Ducha Świętego poprzez sakrament bierzmowania. W: Komisja Duszpasterska Episkopatu Polski: Program duszpasterski na rok 1997/1998. Duch Święty i Jego obecność w Kościele. Katowice 1997 s. 348; por. E. W y s o c k a: Parafia w percepcji i doświadczeniach młodzieży studenckiej. Postrzegane funkcje $w$ życiu codziennym $i$ w kreowaniu tożsamości religijnej. „Socjologia Religii”. T. 1: 2003 s. 124-131; J. K r a s zew sk i: Po dziesięciu latach katechezy w szkole. „Zeszyty Katechetyczne”. R. 1: 2000 nr 16 s. 3-14.
} 
podlegają konsekwencjom działających mechanizmów społeczno-kulturowych. Można mówić o przemianie struktur motywacyjnych wiary, coraz większe znaczenie zdobywaja czynniki wewnatrzosobowe, subiektywne, a traca na znaczeniu instytucjonalne i obiektywne. Oddzialywanie środowiska, także parafialnego, ma charakter coraz bardziej selektywny. Decydują kryteria upodobań, wygody, atrakcyjności, a nieprzystające do oczekiwań wymagania instytucji kościelnej, jaka jest parafia, podlegają krytyce i odrzuceniu. W świadomości ludzi wzrasta psychologiczny opór przeciw jednoznaczności dogmatycznej i radykalizmowi moralnemu Kościoła. Młodzi dość powszechnie odrzucają czynniki instytucjonalne i jurydyczne procesu socjalizacji religijnej ${ }^{9}$.

Duży wpływ na przemiany religijności młodych ma nadal rodzina. Oddziaływanie rodziny pozostaje silniejsze od innych podmiotów socjalizujących, ale dotyczy ono podstawowych orientacji religijnych ${ }^{10}$. Natomiast poszczególne elementy praktycznej realizacji chrześcijaństwa młodzież kształtuje w sposób płynny i niekonsekwentny. Równocześnie coraz słabsza determinacja rodziny w realizacji katolicyzmu jest czynnikiem destabilizującym pewność wiary młodych. Mimo realizacji rytuału, zwlaszcza podstawowych tradycji religijnych, rodziny nie prezentuja konsekwentnego życia wiarą $w$ życiu codziennym. Wzmagają się procesy rozkładu rodziny, wzrasta krytyka wobec wymagań moralnych. W domach prowadzone są dyskusje podważające instytucjonalne racje realizowanej wiary, wiele jest krytycznych opinii o przywódcach religijnych, lokalnych duszpasterzach. Prasa, zwłaszcza ta niskich lotów, wiele stron internetowych, szukając tanich sensacyjek, sięga do obrazoburczych prowokacji związanych z katolicką tożsamością Polaków. Wzmaga się krytykanckie nagłaśnianie grzechów i potknięć przedstawicieli Kościoła. Atmosfera dyskusji i opinii wewnątrzrodzinnych przenosi się na dzieci i młodzież. W skomplikowanych czasach przemian nagminnie poszukuje się winnych zaistniałych trudności, podważa się fundamentalne zasady życia społecznego z uczciwością i prawością na czele. Rozgoryczenie przerzuca się również na oceny dotyczące praktycznej realizacji wyznawanej wiary. Podważa się stałość i niezmienność zasad moralnych. W takiej atmosferze domu rodzinnego wielu gimnazjalistów i przedstawicieli młodego pokolenia traci pewność własnej drogi religijnej. Można mówić u wielu młodych o dystansie wobec oficjalnej nauki Kościoła i zasad katolickich propagowanych przez duszpasterzy ${ }^{11}$.

\footnotetext{
${ }^{9}$ W. P i w o war s k i: Socjologia religii. Lublin 1996 s. 188-195; por. J. M a r i á sk i: W poszukiwaniu sensużycia. Szkice socjologiczno-pastoralne. Lublin $1990 \mathrm{~s} .140-150$.

${ }^{10}$ W. P i wowarski, dz. cyt., s. 106; por. K. P awlin a: Polska młodziez przelomu wieków. Warszawa 1998 s. $110 \mathrm{nn}$.

${ }^{11} \mathrm{~J}$. M a ri án sk i: Socjalizacja religijna i moralna $w$ polskiej rodzinie wspótczesnej. W: Pedagogika pastoralna. Red. M. M a r c z e w s k i. Lublin 2003 s. $118-126$.
} 
Zaprezentowana sytuacja domaga się duszpasterstwa jako wychowania ${ }^{12}$, a więc towarzyszenia w osiągnięciu przez młodego człowieka dojrzalości: ocen, sąu, racji, decyzji, postaw, zachowań itd. Chodzi o asystowanie w dlugim i skomplikowanym procesie usamodzielniania się w odbiorze świata i świadomym kierowaniu własnym życiem. Można mówić o wychowaniu do dojrzalej wiary ${ }^{13}$. W niniejszym opracowaniu skupiamy się na zadaniach duszpasterskich, pominięty więc zostanie szeroki temat „dojrzałej wiary”, jak i zagadnienie „wychowania”.

Duszpasterstwo młodzieży realizowane w parafii powinno uwzględniać specyfikę osobowego i środowiskowego życia młodych. Współczesna młodzież odchodzi od obiektywnych norm moralnych, zdecydowania sklania się ku relatywizmowi, selektywnie akceptuje zasady i wymagania moralno-społeczne. Choć można mówić o dużej wrażliwości duchowej młodych, to jednak ich postawy życiowe opierają się nie na jasnym systemie aksjologicznym, ale na różnych kompromisach moralnych ${ }^{14}$. Młodzi ludzie nie znoszą systemów zamkniętych, zwłaszcza nakazowych. Autorytetem cieszy się u nich imperatyw doznań i krótkotrwałych odczuć. Młodość jest spontaniczna i nowatorska. Dużą wage przywiązuje do wartości duchowych. Rozumie je jednak w sposób indywidualistyczny, nazywany „zgodnością z samym sobą". Wiele wysiłku wkłada w poszukiwanie radości, zabawy, ceni przebywania w gronie przyjaciół lub grupie rówieśników ${ }^{15}$.

Aby wpłynać na wolę i postępowanie młodzieży (docere-muovere), należy akcentować doświadczenie emocjonalne i duchowe (delectare). W działalności pastoralnej należy lączyć poważne i głębokie treści z przystępną formą ${ }^{16}$. Wzrasta rola atrakcyjności propozycji duszpasterskich, które zawierać muszą elementy zabawy, dynamiki i uchu. Naklada to konkretne zobowiązania na duszpasterzy i osoby zaangażowane w aktywność pastoralną. Tradycyjne zadania Kościoła

${ }^{12}$ Zagadnienie „duszpasterstwo jako wychowanie” jest przedmiotem zainteresowania wyłaniającej się coraz jaśniej nowej dyscypliny, którą jest pedagogika pastoralna. Zob. A. F a 11 i c o: Pedagogia pastorale. Questa sconosciuta. Itinerario di formazione per operatori pastorali presbiteri, religiosi e laici. Catania 2000; Pedagogika pastoralna. Red. M. M a r c z e w s k i, dz. cyt.

${ }^{13}$ A. M i c h a l i k: Duszpasterz wczoraj dziś i jutro. Część II. Wybrane zagadnienia duszpasterskie. Tarnów 1997 s. 233n; K. P a w l i n a: Apostolowie nowej ewangelizacji. Warszawa 1996 s. 34 n.

${ }^{14}$ Zob. K. P a w 1 i n a, dz. cyt., s. 63.

${ }^{15}$ Tamże, s. $110-114$.

${ }^{16}$ Duszpasterskie działania mają również charakter perswazyjny, ich celem jest doprowadzenie do akceptacji wartości, stylu postępowania, widzenia rzeczywistości. Można mówić o potrzebie efektywnego propagowania wartości. O stylu prezentacji własnych wartości można mówić w wielu dziedzinach praktycznego działania - por. R. Z e r fa s s: Od aforyzmu do kazania. Kraków 1995 s. $101 \mathrm{n}$. 
lokalnego: katecheza, liturgia, funkcja pasterska - należy realizować w nowy sposób $^{17}$. Katechezę już się przekształca ${ }^{18}$, parafialne życie liturgiczne pozostawia wiele do życzenia, a funkcja pasterska nosi znamiona zaszlościowej marginalizacji. Należy zmienić styl oddziaływań kościelnych z nakazowo moralizatorskiego w przyjacielsko-towarzyszący.

\section{Jakie funkcje parafii są konieczne dla dobrej realizacji duszpasterstwa młodzieży?}

Na działalność parafii, można spojrzeć przez pryzmat funkcji, przez które rozumie się zespół zadań umożliwiających realizację celów parafii, jak również potrzeb jej członków. Funkcje te wynikaja z zadań apostolskich wspólnoty chrześcijańskiej oraz kontekstu spoleczno-kulturowego. Parafia powinna spełniać swoje stałe zadania ewangelizacyjne w ciagle zmieniających się warunkach życia społecznego, uwzględniając nowe potrzeby i oczekiwania ludzi. Dostrzegając, że parafia jest instytucją społeczna, ale i wspólnotą duchową, wyznacza się jej zadania złożone, domagające się działań podmiotu adekwatnego do aktualnych warunków. Elementy instytucjonalno-organizacyjny (widzialny) oraz wewnętrzny, duchowy (niewidzialny) stanowią dwa wymiary tej samej rzeczywistości. Oba sa jakby stopione ze soba, chociaż zachowują teoretyczną odrębność. Pamiętać należy, że sens parafii i jej żywotność oraz rozwój zależy (...) od rozwoju elementu wspólnotowego ${ }^{19}$.

Można wyróżnić podstawowe i uzupełniające funkcje parafii. Pierwsze $z$ nich wynikaja $z$ ewangelicznej misji Kościoła, są stałe i niezmienne, niezależne od przemian społecznych, a są realizowane przez wspólnoty eklezjalne wszystkich szczebli. Należą do nich przepowiadanie słowa Bożego, sprawowanie liturgii i posługa pasterska. Funkcje uzupełniajace to te, które warunkuje kontekst kulturowo-społeczny. Parafia może je pełnić, czasem powinna, ale ich realizacja nie należy do działań istotnych, wpływających na kościelną tożsamość parafii. Tradycyjnie wyróżnia się wśród nich m.in. funkcję integrowania, kontrolowania, kształcenia, rozrywki i wypoczynku. Aktualnie w duszpasterstwie młodzieży istnieje konieczność umiejętnego powiązania zarówno funkcji podstawowych

\footnotetext{
${ }^{17}$ Por. M. P o l a k:, Potrzeba odnowionej wizji parafii w świetle uchwal III Synodu Archidiecezji Gnieźniénskiej (1995-2000). „Teologia Praktyczna”. T. 3: 2002 s. 182n.

${ }^{18}$ K. N y c z: Katecheza a parafia W: Poznać Chrystusa. Komisja Duszpasterstwa Ogólnego Konferencji Episkopatu Polski: Program duszpasterski na rok 2001/2002. Katowice 2001 s. 232 nn.

${ }^{19}$ R. Ka m i ń s k i: Parafia miejscem realizacji duszpasterstwa. W: Teologia pastoralna. T. 2. Red. R. Ka mi ńs ki. Lublin 2002 s. 60n; W. P r z y goda: Funkcje urzeczywistniania sie Kościola. „Roczniki Teologiczne: R. 46: 1999 z. 6 s. 179-189.
} 
parafii, jak i funkcji uzupełniających. Brak owej spójności wydaje się przesądzać dziś o slabej skuteczności duszpasterstwa młodzieży. Tak jak dobry nauczyciel rozumie konieczność realizacji funkcji ludycznej w nauczaniu początkowym, tak duszpasterz młodzieży musi zastosować odpowiednie funkcje w wychowaniu, formacji i duszpasterstwie mlodzieży. Co więcej, jeżeli wspólczesna parafia chce nadal realizować własną misję wśród młodzieży zamieszkującej na jej terenie, niezbędnym zadaniem wydaje się trafne, świadome i efektywne pomnożenie nowych funkcji uzupełniających.

\section{Relacje parafii z młodzieżą w warunkach środowiska pluralistycznego}

Przemiany spoleczno-kulturowe ostatnich lat wpłynęly na zasięg i efektywność duszpasterstwa współczesnych parafii. Nowy charakter relacji społecznych nie pozostał bez wplywu na relacje wewnatrz parafii, odniesienie mieszkańców do różnych instytucji parafialnych, relacje pomiędzy małymi grupami oraz wspólnotami kościelnymi. Wyczerpuja się różne tradycyjne formy ożywiania życia parafialnego. Można mówić o potrzebie poszukiwania nowych sposobów stymulowania interakcji wewnątrzparafialnych. Przemyślenia wymaga dominacja obrzędowości w działalności duszpasterskiej. Katolicy, zarówno duchowni i świeccy, są do tego stopnia przywiązani do schematów i lokalnych sposobów realizacji życia chrześcijańskiego, że zmiana zachowań wydaje się być zdrada bądź wypaczeniem Ewangelii. Tymczasem społeczny, parafialny wyraz życia kościelnego $\mathrm{w}$ dużym stopniu zależy od aktualnego kontekstu społecznokulturowego społeczeństwa.

Należy zdecydowanie zaznaczyć, że nowe działania pastoralne powinny brać pod uwagę przeszłość duszpasterską. Nie należy zatracać pamięci, czy pomijać doświadczenia zdobyte na różnych płaszczyznach duszpasterstwa minionych czasów. Rozpoczynanie odnowy praktyki Kościoła od zera, jakby z pominięciem wcześniejszych dokonań, brak odniesienia do dotychczasowej rzeczywistości duszpasterskiej, byłoby poważnym błędem nie tylko natury praktycznej, ale i teologicznej. Nie zmienia to jednak faktu, że kurczowe trzymanie się starych sposobów działalności duszpasterskiej jest znakiem zatraty zmysłu pastoralnego.

W realizacji duszpasterstwa młodzieży należy przezwyciężyć kilka mechanizmów, zwłaszcza mentalnościowych, krępujących odnowę tej gałęzi kościelnej praktyki. Jednym $z$ nich jest brak odniesień duszpasterstwa młodzieży oraz duszpasterstwa doroslych. Brak jest pewnej ciagłości, zapewniajacej harmonijne przejście, naturalne dojrzewanie do samodzielnego funkcjonowania $w$ świecie 
dorosłych. Spotkać można wiele osób, które w wieku młodzieńczym aktywnie uczestniczyly w duszpasterstwie, a obecnie nie potrafia wyjść poza niedzielne uczestnictwo we mszy św.

W parafialnych propozycjach duszpasterskich zauważa się brak polotu i tzw. „młodzieńczości”. Wiele inicjatyw odwołuje się do tradycyjnych argumentów dewocyjnych, zachęca się młodzież do wzięcia udziału w celebracjach lub wydarzeniach parafialnych apelując do „patriotyzmu lokalnego”, stosuje się retorykę nieprzystającą do mentalności osób młodych. Sam przebieg nabożeństw i celebracji swoją schematycznością i rytualizmem zniechęca młodych, zwlaszcza osoby nie mające wsparcia religijnego kontekstu rodziny.

Nierzadkim powodem inicjatyw duszpasterskich w parafii jest „walka” o młodzież. Tymczasem młodzi ludzie nie chca "dostarczać kuponów” żadnym instytucjom o nich zabiegajacym. Brak autorytetu księdza w środowiskach młodzieży motywowany jest również racją: bo księdzu na mnie nie zależy ${ }^{20}$. Młodzi docenią duchową bliskość prawdziwego wychowawcy, a natychmiast rozszyfrują brak autentyzmu. Przylgną do autentycznego przyjaciela, mistrza i przewodnika, a odrzucą zewnętrzny, urzędowy styl „belfra” odgórnie domagającego się posłuchu $^{21}$. Kapłanom, animatorom duszpasterstwa młodzieży należy zapewnić dobre przygotowanie, które musi jednak zasadzać się na charyzmatycznych predyspozycjach wychowawczych. Nie wszyscy kapłani nadają się do skutecznego realizowania duszpasterstwa młodzieży, a aktualnym kryterium przydziału tych zadań wydaje się być zbyt często jedynie młody wiek księdza.

Innym obciążeniem jest zacieśnianie aktywności duszpasterskiej do wąskiego grona osób tzw. „związanych" z parafią. Mowa jest o „spotkaniach grupy”, o akcji „dla osób należących”, o wyznaczonym terminie, aby młodzież przyszła na spotkanie. Wśród wielu atrakcyjnych propozycji w różnych środowiskach życia, młodzi ludzie nie są w stanie dokonać wyboru aktywności parafialnej z tzw. ogłoszeń parafialnych. Młodzież kontestuje również przerost rytualizmu w działaniach duszpasterskich, brak radości, beznamiętną obrzędowość oraz słabo umotywowane imperatywy.

Tymczasem obserwuje się duży rozdźwięk wiary i życia młodzieży oraz dystans między katechezą szkolną i parafią. Wyobcowanie z parafii pogłębia nierzadkie odprawianie rekolekcji szkolnych poza środowiskiem parafialnym. Obserwować można mniejszą dynamikę młodzieżowych grup kościelnych. Spośród grup zachwycających swą żywotnością wyróżniają się raczej te pozaparafialne,

${ }^{20}$ Por. K. P a w 1 i na, dz. cyt., s. 61.

${ }^{21}$ Por. A. Gó r s k a: Model wspótczesnego katechety w świetle badań. „Zeszyty Katechetyczne”. R. 2: 1998 nr 9 s. 35-40; T. P a n u ś, dz. cyt., s. 145. 
związane z ruchami, ideą wspólnoty Taizé itp. Choć pojawiaja się pozytywne wyjątki, można mówić o niebezpiecznym procesie zaniku tradycyjnych relacji parafii z młodzieża. Pojawiają się pytania o kierunki odnowy: Czym jest wspólczesna parafia dla młodzieży? Jak parafia powinna rozumieć swoją tożsamość? $\mathrm{Na}$ czy powinny polegać działania parafii w aktualnej, pluralistycznej rzeczywistości współczesnego świata? Jakich działań młodzież oczekuje od parafii? Co może parafia zaproponować młodzieży, aby stawała się dla niej rodzinną wspólnotą lokalną? Tych pytań można postawić więcej, jednak oczywistą wydaje się potrzeba przemyślenia funkcji oraz struktur parafii w odniesieniu do mlodych. A to oni są „nadzieją Kościoła”. Czy ta wielka przyszłość Kościoła, jaką są mlodzi, wzrastać ma do autentycznego chrześcijaństwa obok parafii, czy raczej wewnątrz odnowionej parafii?

\section{Odnowa zasad organizacji duszpasterstwa młodzieży}

Zasada obecności Kościoła oraz jego duszpasterstwa pośrodku życia młodzieży nie jest postulatem nowym. Jednak w obecnych czasach relacje parafii oraz społeczności lokalnej zmieniają się coraz intensywniej. Jest rzeczą naturalna, że środowisko młodzieżowe oraz jego duszpasterstwo podlega zmianom szybszym i glębszym.

Tymczasem we współczesnym duszpasterstwie młodzieży można dostrzec ciaggle obowiązująca spuściznę tradycyjnego stylu duszpasterstwa. Młodzieży proponuje się aktywność jednej bądź kilku grup młodzieżowych, których działalność sprowadza się do spotkań w budynkach parafialnych, formacji duchowej, jakiejś formy inicjatyw apostolskich. Z badań przeprowadzonych na Śląsku, a więc $\mathrm{w}$ środowisku specyficznie zintegrowanym i stosunkowo tradycyjnym, wynika, że 40,5\% młodzieży wie o działalności wspólnot w ich parafii, 13\% określiło siebie jako aktywnych uczestników życia wspólnotowego, a 6\% jako uczestniczących w spotkaniach wspólnot od czasu do czasu. Aż $74 \%$ młodych ludzi powiedziało, że nie uczestniczy w żaden sposób w jakichkolwiek przejawach życia wspólnotowego w parafii, a $5 \%$ nie udzieliło żadnej odpowiedzi ${ }^{22}$. Wynika stąd, że $80 \%$ mlodzieży nie jest związanych ze wspólnotowymi formami duszpasterstwa, zaś pozostałe $20 \% \mathrm{w}$ różnym stopniu uczestniczących w życiu małych grup i wspólnot, to prawdopodobnie osoby biorące udział w niedzielnej mszy św. Można przypuszczać, że w innych rejonach Polski, w środowiskach mniej tradycyjnych, uczestnictwo młodzieży w aktywności grup parafialnych

\footnotetext{
${ }^{22}$ A. G ó r n y: Mlodzież a parafia. Obraz parafii w świadomó́ci młodzieży w województwie ślqskim. „Socjologia Religii”. R. 2003. T. 1 s. 141.
} 
jest jeszcze mniejsze. Wynika stąd, że wspomniane grupy nie maja wplywu na cale środowisko mlodzieży. Sprawiają one czasem wrażenie wąskich i zamkniętych gett, w których dominuje styl samozadowalającej stabilizacji, spokojnej „parafiańszczyzny”, mało twórczego i ustabilizowanego samozadowolenia. Rzadko kiedy parafialne grupy duszpasterstwa młodzieży stają się awangardą życia środowisk szkolnych oraz naturalnych obszarów realizowania się młodych. Są bardziej odskocznią dla młodego człowieka, miejscem wyjętym poza nawias ich codzienności, pewnego rodzaju enklawa, aniżeli zaczynem w świecie. Jeżeli nawet uzasadnione są i takie formy propozycji pastoralnych parafii, to nie zmienia to faktu, że zadanie objęcia zasięgiem duszpasterskim calej młodzieży własnego terytorium nie jest przez parafię wypełnione. Można mówić o wąskim gronie osób, o elicie młodych związanych z życiem Kościola lokalnego.

Przeniesienie katechizacji do szkół w znacznym stopniu skomplikowało relacje parafii z młodzieża. Ocena realizacji katechizacji w szkole nie wchodzi w zakres niniejszych analiz, jednak bezsprzecznie można mówić o wielorakim wpływie katechizacji szkolnej na zmianę kształtu duszpasterstwa parafialnego. Zauważa się oddalenie młodzieży od parafii na skutek przesunięcia owego punktu ciężkości, jakim jest katechizacja. Wcześniejszy, przyparafialny model katechizacji ułatwial angażowanie młodzieży w aktywność parafialna, a zwłaszcza mobilizował do sumienniejszych praktyk sakramentalnych ${ }^{23}$. Duszpasterzom nie udało się jak dotychczas znaleźć jakiegoś klucza, sposobu ścisłej współpracy katechizacji szkolnej z parafią. Podejmowane są różne próby organizacji pojedynczych akcji: konkursów, celebracji, dni młodzieży, koncertów itp., ale są to działania raczej jednorazowe. Widoczny jest zatem duży dystans młodzieży wobec życia parafialnego, zwlaszcza sakramentalnego.

Jest wiele innych zależności historyczno-kościelnych oraz mechanizmów społecznych, które wpływają na marginalizację roli parafii w duszpasterstwie młodzieży (nowoczesny styl życia - kursy, sport; nowy model rodziny; świeckie przeżywanie dni wolnych, zwłaszcza piątków, sobót i niedziel).

Powstaje pytanie o nową mentalność strategów duszpasterstwa, proboszczów, kapłanów oraz pracowników duszpasterstwa młodzieży, a także nowe przedsięwzięcia parafii w celu wychodzenia naprzeciw owym tendencjom. Młodość wraz ze swoją witalnością oraz zdolnością przenikania środowiska wnosi dynamizm, a czasem różne napięcia. Osoby zaangażowane w duszpasterstwie młodzieży powinny posiąść podwójną umiejętność: uważnego i zaangażowanego wyczucia młodzieńczego dynamizmu oraz konsekwentnej realizacji obiektywnego projektu formacji wiary. Można mówić o konieczności posiadania umiejęt-

\footnotetext{
${ }^{23}$ S. H. Z a r ę b a, dz. cyt., s. 122 n.
} 
ności praktycznych powiązanych z odpowiednią duchowością posługiwania. Być duszpasterzem mlodzieży, znaczy stanąc u boku młodego czlowieka, czy grupy mlodzieży, wychodząc od jej aktualnej sytuacji i towarzysząc jej nieprzerwanie, podążać w kierunku obiecanego dobra osobistego, doczesnego i wiecznego.

Decydujące znaczenie dla skuteczności oddziaływań duszpasterskich wobec młodzieży ma znajomość źródeł i sposobów kształtowania sumień osób młodych. Nie bez znaczenia jest określenie miejsc i okoliczności przynależności chrześcijańskiej młodzieży. Zarówno więc wpływ na formowanie sumień osób młodych, jak i kontakt $z$ ich środowiskami domaga się przebywania z młodzieżą, wśród problemów ich życia codziennego. To z kolei wskazuje na kolejne ważne zagadnienie: umiejętne powiązanie realizacji zwartego projektu z zaangażowaniem młodych. Propozycje duszpasterstwa młodzieży powinny posiadać nowe jakościowo cechy, których często nie jest w stanie zapewnić sama tylko para$\mathrm{fia}^{24}$.

We współczesnych warunkach życia społeczno-religijnego niezbędny jest konkretny projekt duszpasterstwa młodzieży. Mając na myśli miasto, dużą parafię, a nawet małą społeczność kościelną żyjącą w pluralistycznym świecie, zauważyć można spory dystans pomiędzy centrum duszpasterstwa a obrzeżami, peryferiami społeczności. Można mówić o mechanizmie wielokrotnego pośredniczenia w aplikowaniu treści oraz środków duszpasterskich. Jakikolwiek projekt duszpasterski nie może być narzucony z góry. Istnieje w takim wypadku ryzyko odrzucenia go przez środowisko młodzieży, gdyż nie trafi w jej potrzeby, będzie teoretyczny, przechodzący „ponad głowami”. Wszelkie propozycje instytucjonalne, wskazania centralne powinny zawierać możliwości adaptacji i transformacji programu do okoliczności oraz mentalności danego środowiska młodzieży.

Osiągnięcie zaangażowania młodych w realizację duszpasterstwa młodzieży domaga się trafności propozycji zaprezentowanych w projekcie. Powinny mieć one charakter wyprzedzający w stosunku do dylematów i niepokojów młodzieży. Gdy propozycje te przetrwają próbę życia, objawią swoją aktualność, ukażą drogę i pomoc w promowaniu mlodzieńczych ideałów, można będzie liczyć na współpracę i zaangażowanie młodzieży $\mathrm{w}$ realizację kolejnych faz projektu duszpasterskiego. Właśnie angażowanie się poszczególnych osób, grup, stowarzyszeń, ruchów, zdobywanie zwolenników z sąsiednich parafii i wspólnot, może świadczyć o żywotności i autentyczności duszpasterstwa. Witalność, dynamika i świeżość w działaniach pastoralnych wśród mlodzieży są niezbędne, aby uzyskać jej zaufanie i otwartość na propozycje „centrali” duszpasterstwa.

\footnotetext{
${ }^{24}$ A. N a p o 1 i o n i: La srada dei giovani. Prospettive di pastorale giovanile. Milano $1994 \mathrm{~s}$. $61 n$
} 
Jest to decydujący moment przedsięwzięcia, jakim jest duszpasterstwo młodzieży: przejście od modelu nakazowo-instytucjonalnego do modelu interaktywnego. Akcent stawiany jest nie na uzasadnianie słuszności zasad projektu duszpasterskiego, ale na zmianę mentalności, bez której nie da się „przepracować” kultury życia młodzieżowego. Trzeba trafić w centrum świata przeżywanego przez młodych, wpleść dzialania duszpasterskie w ich sposób odbioru - dotykalny, bezpośredni, naturalny, a wtedy będą chcieli odpowiedzieć na propozycje, aby skosztować radości odkrywania wartości zaproponowanych w projekcie. Zaryzykuja wyjście z wlasnych schematów i przyzwyczajeń, gdy przejście do duszpasterskich propozycji nie będzie domagało się porzucenia własnego „świata". Trzeba stanąć w centrum, pośród życia młodych ludzi i ukazując radość i świeżość Ewangelii, zaproponować wspólną droge do szczęśliwych przeznaczeń. Odpowiedź młodego człowieka będzie pozytywna, jeżeli propozycja skierowana będzie do konkretnego życia, wewnątrz naturalnych relacji środowiskowych, z udziałem naturalnych przedstawicieli ich środowiska ${ }^{25}$.

Charakter decydujący propozycji duszpasterstwa młodzieży polega więc na zmianie perspektywy oraz metod działania. Zasadza się na obecności wewnątrz świata i życia młodych $\mathrm{z}$ ich naturalnym zaangażowaniem ${ }^{26}$. Mówiąc innymi słowami: niewykonalna jest jakakolwiek propozycja duszpasterstwa młodzieży z udziałem gimnazjalistów, młodzieży, animatorów, księży - przychodząca z góry, próbująca dosięgnąć dołów i peryferii życia młodzieżowego. Konieczne jest przejście do bezpośrednich relacji i wspólnego konstruowania działań duszpasterstwa młodzieży w środowiskach życia młodzieży. Współczesne parafie nie w pełni realizują wspomniane zasady w propozycjach parafialnego duszpasterstwa młodzieży.

\section{Rola parafii w przyszłościowym duszpasterstwie młodzieży}

Parafia rozumiana tradycyjnie coraz trudniej może podołać współczesnym oczekiwaniom młodzieży wobec Kościoła i jego duszpasterstwa. Pauperyzacja społeczeństwa ogranicza również w znacznym stopniu faktyczne możliwości działania w ramach parafii. Mówiąc o duszpasterstwie we współczesnym świecie należy używać coraz częściej pojęcia „Zespoły Duszpasterskie” (ZD) oznaczają-

\footnotetext{
${ }^{25}$ Tamże, s. 63-68; por. K. O ż ó g: Wartości i wartościowanie w języku wspólczesnej mlodzieży. "Via Consecrata”. T. 1: 2004 s. 50-52.

${ }^{26}$ Por. J. M a ri án s ki: Kościót a wspótczesne problemy społeczno-moralne. Kwestie wybrane. Lublin 1992 s. 243.
} 
cego jakościową zmianę $\mathrm{w}$ praktyce Kościoła ${ }^{27}$. Chodzi o dowartościowanie współpracy grup specjalistów, którzy kompetentnie organizują poszczególne obszary duszpasterskie. Decydującą rolę odgrywa projekt, plan realizacji, organizacja, etapy działania, koordynacja, przygotowanie zespołów realizujących poszczególne zadania itd. Chodzi o respektowanie zasad zorganizowanego działania w zlożonych warunkach życia ${ }^{28}$.

Zespoły Duszpasterskie to nazwa nowej rzeczywistości, której kierunku rozwoju nie możemy obecnie określić. Doświadczenie wskazuje na coraz większą potrzebę realizowania praktyki Kościoła w formie „duszpasterstwa razem” ${ }^{29}$. Trudno wskazać konkretne formy tej aktywności pastoralnej, czy będzie to raczej współpraca w ramach rejonu, miasta, osiedla, czy duszpasterstwo dekanalne, międzyparafialne, bądź multiparafialne. Z pewnością jednak efektywność praktyki Kościoła związana jest $\mathrm{z}$ nową jakościowo pracą duszpasterską, ze wspólnym wysiłkiem w określonym porządku, co nazwać można „duszpasterstwem razem". Takie ujęcie zaklada osiaganie pewnej wizji wspólnoty Kościoła żyjącej w różnych miejscach spoleczności lokalnej. Chodzi również o takie rozumienie duszpasterstwa, które pozwoli unikać rozproszenia i rozdrobnienia zarówno w obciążeniu duszpasterzy, jak i konkretnych akcji duszpasterskich. Niepotrzebne jest bowiem kopiowanie tych samych, pojedynczych inicjatyw przez sąsiadujące z sobą parafie, powodujące niepotrzebne rozdrobnienie. Działania mogą być bardziej efektywne w ramach współpracy dekanalnej, rejonowej, międzyparafialnej. Wspólny projekt działania, kompetentny zespól pastoralny, współpraca specjalistów i bogatsze środki moga gwarantować lepsze efekty duszpasterskie.

Odpowiedź na potrzeby duszpasterskie nie może polegać na klonowaniu przez każdą wspólnotę kościelną takiej samej serii działań oraz struktur, jakby wszystkie parafie miały robić to samo. "Duszpasterstwo razem" powinno stawać się stylem także tych parafii, które wydają się być stosunkowo duże i posiadają odpowiednią liczbę duszpasterzy.

Wyzwanie związane $\mathrm{z}$ działalnością Zespolów Duszpasterskich dotyczy z pewnością wszystkich. Po okresie pionierskich dokonań niektórych parafii, bądź poszczególnych kapłanów, nadszedł czas nowego sposobu myślenia o całym duszpasterstwie. Ma się ono stawać głoszeniem Ewangelii oraz budowaniem wspólnoty wewnątrz, pośród życia ludzi ${ }^{30}$. Wymaga to wprowadzenia w ruch

${ }^{27}$ Por. K. R e d l a k: Nowe formy aktywności duszpasterskiej laikatu na przykladzie aktualnych doświadczeń Kościola we Francji. „Teologia Praktyczna”. T. 3: 2002 s. 33-36.

${ }^{28}$ Zob. F. G. B r a m b i 11 a: La parrocchia oggi e domani. Assisi 2003 s. 263-268.

${ }^{29}$ Tamże, s. 49.

${ }^{30}$ Por. J. M a r i a ń s k i, dz. cyt., s. 121. 
całego środowiska. Pomysly i projekty dzisiejsze, jutro powinny być dynamicznie realizowane. Efektem ożywienia wspólnot kościelnych powinno być widoczne ożywienie środowisk parafialnych, nowe sily i energie, glównie spośród osób świeckich. Należy powoli lecz systematycznie i ostatecznie odchodzić od identyfikowania aktywności parafialnej z proboszczem. Przeżytkiem są dziś parafie niezależne i samowystarczalne ${ }^{31}$. Nie oznacza to oczywiście końca parafii jako takiej, gdyż Kościół nie może zaniechać objawiania swojej obecności w konkretnym miejscu i czasie. Jednak obecność Kościoła w środowisku podlega ewolucyjnym zmianom umożliwiającym realną służbę wobec konkretnych potrzeb parafian.

\section{Rola rejonu duszpasterskiego w duszpasterstwie młodzieży}

Gdy przyjrzymy się miejscom obecności młodzieży, środowiskom w których przebywają, okaże się że parafia zamieszkania często jest marginalnym miejscem ich pobytu. Uczą się poza parafią, organizują również poza nią swoje zajęcia pozalekcyjne, zainteresowania, sport i rekreację. Z tych racji dla skuteczności duszpasterstwa młodzieży należy docenić rolę większego rejonu niż parafia. Można przyjąc, że skuteczniejszym obszarem organizacji duszpasterstwa młodzieży jest dekanat ${ }^{32}$.

Duszpasterstwo młodzieży w dekanacie skierowane jest przeważnie do gimnazjalistów i młodzieży za pomoca inicjatyw zbierających młodzież. Moga to być jednostkowe bądź cykliczne propozycje adresowane do różnych grup młodych. Konieczny jest wysoki stopień atrakcyjności podejmowanych działań. Domaga się to profesjonalnego przygotowania w oparciu o kompetentny zespót animatorów. Niezbędna jest więc działalność dekanalnej (rejonowej) ekipy duszpasterstwa młodzieży pod kierunkiem dekanalnego moderatora, którym powinien być odpowiedni kapłan. Zasadniczą cechą duszpasterza dekanalnego jest bez wątpienia dobry kontakt i porozumienie z młodzieżą. Najlepiej do funkcji tej nadaje się kapłan pełniący rolę katechety w gimnazjum lub liceum, do którego uczęszcza młodzież z kilku parafii. W sytuacji, gdy uczniowie uczący się w szkole pochodzą $z$ wielu parafii, można zaproponować działania rejonowe, albo cykl przedsięwzięć wzmagających współzawodnictwo między poszczególnymi dekanatami. W takiej sytuacji do współpracy należy zaangażować dwa albo nawet więcej dekanatów.

\footnotetext{
${ }^{31}$ Por. Te n ż e: Kościól katolicki w spoleczeństwie obywatelskim. Refleksje socjologiczne. Lublin 1998 s. 149 n.

${ }^{32}$ R. K a m i ń s k i: Duszpasterstwo ponadparafialne. „Roczniki Teologiczne”. R. 45: $1998 \mathrm{z}$. 6 s. $54-58$.
} 
Charakter podejmowanych inicjatyw zależy od celu, jaki zaklada sobie dekanalna ekipa duszpasterstwa mlodzieży. Pamiętając o atrakcyjnym charakterze podejmowanych dzialań należy dobrze przemyśleć pojawiające się pomysly. Nie jest celem niniejszego opracowania podawanie możliwych, praktycznych rozwiązań, ale pomysłów może być wiele. Centrum aktywności powinna być formacja-animacja chrześcijańska, a więc modlitwa, katecheza, szkoła apostolstwa. Jednak oczywista jest właściwa forma odpowiadająca stylowi młodzieży, zawierająca dynamikę, radość, spontaniczne i przekonujące formy wyrazu. Niezbędna jest więc muzyka, śpiew, albo refleksja oraz nastrój w małych grupach. Odpowiednie aspekty działań powinny być przedmiotem szczegółowych przygotowań ustalonych ekip-diakonii. W ich skład powinni wchodzić młodzi przedstawiciele grup kościelnych, ruchów, szkół ewangelizacji.

Niezbędne jest uprzednie przygotowanie projektu podejmowanego przedsięwzięcia, szczegółowy plan, etapy działania, cele jednostkowe, środki, metody i przewidywane reakcje. Należy wyznaczyć odpowiedzialnych, koordynatorów, a przede wszystkim zgromadzić potrzebne środki. Zwłaszcza te ostatnie wydają się być ważnym problemem $\mathrm{w}$ dobie zubożenia społeczeństwa i ekonomicznego niedowladu spoleczeństwa. Niezbędne jest jednak inwestowanie w przedsięwzięcia związane z duszpasterstwem mlodzieży. Rozumieją to proboszczowie, a często i sponsorzy, którzy są gotowi wspierać dzieła autentyczne, żywotne, poruszające środowisko, a takim dziełem powinna być każda propozycja duszpasterstwa młodzieży na szczeblu dekanalnym bądź rejonowym.

Choć już wcześniej była o tym mowa, jeszcze raz należy podkreślić rolę kapłana-moderatora w efektywności działań rejonowego ośrodka duszpasterstwa ${ }^{33}$. Powinien być on osobą znającą środowisko młodzieży, rozumiejąca specyfikę jej środowiska, dostrzegająca charakterystyczne cechy poszczególnych parafii, szkól, środowisk lokalnych, a nawet rodzin swoich wychowanków. Wiąże się to z potrzebą dłuższej pracy w dekanacie, minimum 4-5 lat. Niezbędne jest więc współdziałanie inicjatyw dekanalnego duszpasterstwa młodzieży z kurią biskupia, aby odgórnie mogly być wspierane wspomniane inicjatywy. Wiąże się to $z$ pozostawianiem księży na dłuższy okres $\mathrm{w}$ parafiach, aby mogli wejść w środowisko mlodzieży i stać się autentycznymi promotorami jej chrześcijańskiego dojrzewania. Ważna jest również współpraca ze specjalistami oraz środowiskami świeckimi, ale będzie o tym mowa w innym miejscu.

${ }^{33}$ F. G. B r a m b i 11 a, dz. cyt., s. 130; por. Kongregacja ds. Duchowieństwa: List okólny Kapłan głosiciel słowa, szafarz sakramentów i przewodnik wspólnoty $w$ drodze do trzeciego tysiqclecia chrześcijaństwa. Tarnów 2000 s. 63nn. 
Dekanalne inicjatywy duszpasterstwa młodzieży muszą mieć poparcie poszczególnych proboszczów tworzących prezbiterium rejonowe. Dlatego niezbędna jest otwartość umyslu, kompetencja oraz zdatność kandydatów na proboszczów współczesnych parafii. Kryteria doboru powinny więc stanowić sprawności, kompetencje kapłanów, a zwlaszcza otwartość umysłu i gotowość do wspólpracy. Zacieśnianie duszpasterstwa do terytorium parafii, waski i lękowy minimalizm, brak odwagi oraz szerokości patrzenia, są nieprzezwyciężalnymi przeszkodami realizacji współczesnych form duszpasterstwa, zwłaszcza duszpasterstwa młodzieży . Proboszczem współczesnej parafii może być osoba zdolna do współpracy w ekipie i rozumiejąca aktualną dynamikę społeczno-eklezjalna.

Inicjatywy rejonowego duszpasterstwa młodzieży, jak to już zostało zaznaczone wcześniej, powinny otrzymać poparcie różnych szczebli strukturalnomaterialnych poszczególnych parafii. Niezbędne jest wsparcie parafialnych rad duszpasterskich poszczególnych parafii, pojedynczych osób dorosłych służących rada, konkretną pomocą i doświadczeniem. Dobre efekty może przynieść włączenie się rodziców młodzieży, przez co atmosfera świętowania i chrześcijański klimat przeniosą się do rodzin oraz sąsiedztwa młodzieży. Ma to znaczenie tak apostolskie, jak i promocyjne, a owocność ewangelizacyjna zyskuje aprobatę środowisk świeckich.

Nie wszystkie inicjatywy dekanalnego duszpasterstwa młodzieży mogą mieć stosunkowo duży zasięg i szeroki rozmach. Często drobne akcje, pojedyncze inicjatywy lokalne moga stanowić niezbędne uzupełnienie szerokich działań w ramach dekanatu. Małe inicjatywy powinny spełniać jednak przynajmniej dwie cechy: powinny być autentyczne oraz stałe. To zagwarantuje apostolską skuteczność nawet najmniejszym propozycjom ${ }^{34}$.

Wspomnieć również trzeba o bazie lokalowej dla działalności dekanalnego duszpasterstwa młodzieży. Należy pamiętać, że prawie w każdej parafii istnieja dawne salki katechetyczne. Wiele $z$ tych pomieszczeń może pełnić doskonała rolę klubu, kawiarni, czy centrum danej aktywności (grupy). Parafia to jednak nie tylko budynki kościelne, ale duże terytorium osiedlowe, obszar ze spolecznością lokalną. Użytkowane są w niej pomieszczenia szkolne, rad osiedlowych, gminnych, domy kultury, kluby różnych organizacji i stowarzyszeń, świetlice, harcówki itp. Najlepszym miejscem wydaje się szkoła, w której opiekę sprawować może nad grupą mieszkający w parafii nauczyciel, najlepiej będący również animatorem bądź przedstawicielem struktur parafialnych.

34 Por. R. Ka mi ńs k i: Główne kierunki pracy duszpasterskiej Kościola w Polsce. W: Duszpasterstwo a wyzwania XXI wieku. Materiały z sympozjum Pastoralistów Polskich 22-24 kwietnia 2001. Red. J. Os t r o w s k i. Kielce 2001 s. 55n. 
Szczególnym przypadkiem rejonu duszpasterskiego może być niewielkie miasto, w którym istnieją 2-3 parafie. Jest to środowisko tym bardziej przystajace do prezentowanej koncepcji rejonowego duszpasterstwa mlodzieży, które możemy nazwać w tym przypadku miejskim duszpasterstwem mlodzieży ${ }^{35}$. Wszystko, co zostało powiedziane o poszczególnych aspektach dekanalnego duszpasterstwa młodzieży, jest tym łatwiejsze do zrealizowania w ramach małego bądź średniego miasta. Zarówno młodzieżowe zespoły ludzkie, dobór współpracowników dorosłych, specjalistów, jak i zgromadzenie środków, pomocy materialnej i technicznej, wydają się być łatwiejsze w atmosferze familijnej niedużego środowiska. Przezwyciężać natomiast należy zacieśnianie umysłu, zawiść i pojawiające się w spolecznościach konflikty oraz animozje.

Dekanalne inicjatywy duszpasterstwa młodzieży są potrzebą chwili w społeczeństwie coraz bardziej dynamicznym, powiązanym siatką relacji i więzi spolecznych, pozbywającym się ciasnych granic. W dobie znacznej mobilności, gdy miejsce zamieszkania nie pokrywa się z miejscem pracy, odpoczynku bądź spędzania wolnego czasu, ograniczanie się do podległości inicjatywom parafialnym nie zapewnia młodzieży ani skutecznej formacji religijnej, ani efektywnej animacji społeczno-kościelnej. Niezbędne są inicjatywy międzyparafialne, a dobrym środowiskiem skutecznie wspierającym działalność duszpasterską parafii wydaje się być dekanat. Tym bardziej, że młodzi ludzie dzięki zajęciom szkolnym, własnym zainteresowaniom, a przede wszystkim młodzieńczemu entuzjazmowi, znajdują naturalne sposoby przenikania do szerszego środowiska.

\section{Duszpasterstwo młodzieży jako przenikanie się środowisk}

Mówiąc o inicjatywach duszpasterstwa młodzieży w relacjach parafii oraz środowisk świeckich niezbędna jest krótka refleksja historyczna. Wielu współczesnych reprezentantów społeczności lokalnych zostało uformowanych przez miniony system, w którym w ramach tzw. zasady świeckości państwa, nakazowo wprowadzono zakaz współdziałania przedstawicieli struktur społecznych i państwowych z przedstawicielami struktur kościelnych. Krótko mówiąc, szykanowane były osoby sprawujące różne funkcje administracyjne czy społeczne, które przyznawały się do praktykowania wiary, utożsamiały się z parafią, a co najgorsze afirmowały w jakikolwiek sposób wartości religijne i kościele. Po kilkunastu latach przemian w Polsce zauważa się nadal pozostałości mentalnościowostrukturalne blokujące promocję ogólnoludzkich wartości propagowanych przez Kościół. Dla wielu reprezentantów życia społecznego nadal niezrozumiała jest

\footnotetext{
${ }^{35}$ Por. R. Ka m i ń s k i, dz. cyt., s. 59n.
} 
pozytywna rola wartości ewangelicznych w wychowaniu, szkolnictwie, gospodarce, polityce itd. Co więcej, w społeczeństwie w przeważającej większości katolickim, pojawiają się przedstawiciele tego spoleczeństwa pełniący funkcje społeczno-administracyjne, którzy zamiast reprezentować ludzi i działać w ich interesie, czują się jakby właścicielami kierowanych gremiów. Takie osoby odpowiedzialne za szkoły, instytucje społeczne, przedstawicielstwa różnych organizacji itp. utrudniają często współpracę owych instytucji z parafią.

W warunkach życia społecznego opartego na systemie demokratycznym duszpasterstwo młodzieży może oczekiwać, a nawet domagać się, wszechstronnych możliwości wspólpracy Kościoła z szeroko rozumianym środowiskiem. Na czoło instytucji spolecznych naturalnie odpowiadających inicjatywom młodzieżowym wysuwa się z pewnością szkoła. To na terenie szkoły, przy znacznym poparciu dyrekcji, grona pedagogicznego i poszczególnych instancji pośrednich (świetlicy, bazy technicznej, lokalowej, harcówki, stołówki, kół zainteresowań, zespolów pracy pozalekcyjnej itd.) można dopatrywać się naturalnych sojuszników inicjatyw duszpasterstwa młodzieży ${ }^{36}$. Mogą to być działania wychowawcze, sportowe, kulturalne, ekologiczne, artystyczne, itd. prowadzące do promocji tego co ludzkie, związane z kategoriami dobra i piękna.

Podobną rolę aktywnych współpracowników mogą pełnić społeczne gremia rad osiedlowych, miejskich czy gminnych, wraz z podległymi im strukturami. Warto wyróżnić pośród nich osiedlowy, miejski, oraz gminny dom kultury, który ze swej istoty pełni rolę naturalnego sojusznika wartości propagowanych w duszpasterstwie mlodzieży. Właśnie na szczeblu naturalnej lokalności wiele inicjatyw duszpasterstwo młodzieży zyskać może zrozumienie i konkretną pomoc. To rodzice młodych zasiadaja w radach, oni wybierają swoich przedstawicieli, a wielu młodych już w niedalekiej przyszłości zasiądzie w lawach tych społecznych struktur. Wzajemne wsparcie, otwartość na proponowane programy i inicjatywy powinny stanowić fundamentalną zasadę wspólistnienia parafii, dekanatu oraz rad środowiskowych. Trudno wyobrazić sobie dzisiaj promocje wartości duchowych oraz religijnych w oderwaniu od kontekstu życia, mieszkania i działalności rodzin osób młodych. Jest to płaszczyzna współpracy ciagle jednak nie do końca wykorzystana.

Współczesne społeczności doceniają w coraz większym stopniu rolę sportu, rekreacji i wypoczynku. Powstają coraz bardziej profesjonalne inicjatywy spoleczne oraz komercyjne na potrzeby sportu i rekreacji. Wydaje się koniecznym nawiązywanie ścisłej współpracy $\mathrm{z}$ tymi inicjatywami ze strony duszpasterstwa

${ }^{36}$ Zob. E. P o r a d a: Z namyshu nad kościelnościq ludzi obojętnych. W: W trosce o Kościót. Kościól poza Kościolem. Red. K. K ow a li k, A. J a r z ą b e k, V. K m i e c i k. Lublin 2001 s. 47. 
mlodzieży ${ }^{37}$. Mogą to być wspólne imprezy, korzystanie z obiektów, wlączanie się z własnym programem w trakcie imprez i przedsięwzięć klubów i organizacji, aby chrześcijańskie przesłanie wiązało się $\mathrm{z}$ dynamizmem i żywotnością dająca prawdziwą radość. Zarówno atmosfera emocji i radości, czy spokoju i ciszy, jak i zdrowe wspólzawodnictwo, naturalnie wspierają ewangeliczne przesłanie promocji człowieka i tego co ludzkie. W przypadkach szczególnych warto zakładać własne, chrześcijańskie i katolickie kluby i organizacje sportowe czy rekreacyjne. Na kanwie ich aktywności działalność duszpasterstwa młodzieży może uzyskać znaczną akcelerację oraz skuteczność ${ }^{38}$.

Doskonałą formą uaktywniania młodzieży jest skauting. Jego rozwój zarówno w strukturach kościelnych, jak i świeckich, świadczy o ponadczasowym przesłaniu i naturalnej wymowie. W ostatnich latach pojawily się kolejne odłamy formacji harcerskich, które akcentują własną specyfikę, programy i uszczegółowiają kodeksy wartości. Należy się im poparcie ze strony parafii oraz innych struktur kościelnych, aby w naturalny sposób pelniły również rolę duszpasterską. Warte podkreślenia jest promowanie przez ruch skautowy kontaktu z przyroda, który wydaje się być coraz trudniej zaspokajaną potrzebą współczesnych społeczeństw. Przy drużynach harcerskich mogą rozwijać się inne inicjatywy duszpasterstwa młodzieży, jak wycieczki, rajdy, ogniska, zabawy w terenie, wyjazdy rowerowe itp. Atmosfera tego typu aktywności jest szczególnie efektywna w duszpasterstwie młodzieży. Stwarza również sprzyjające warunki do kontaktu ze Stwórca, wyrabiania naturalnej wrażliwości sumienia oraz innych cech osobowości. Zagadnienie ekologii ducha znajduje w inicjatywach skautingu optymalne warunki rozwoju ${ }^{39}$.

${ }^{37}$ P. K v a te r n i k: Duszpasterstwo rodzin wobec wyzwań czasu wolnego. „Teologia Prak tyczna”. T. 3: 2002 s. $134 \mathrm{nn}$.

${ }^{38} \mathrm{~W}$ ostatnim dziesięcioleciu wzrasta zainteresowanie Kościoła działalnością duszpasterską w powiązaniu ze sportem, turystyką oraz spędzaniem czasu wolnego - por. Tempo libero, turismo e sport. Sussidio pastorale del' Ufficio nazionale della CEI per la pastorale del tempo libero, turismo e sport. Milano 1993; II Papa agli sportivi. Ufficio nazionale della CEI per la pastorale del tempo libero, turismo e sport. Milano 2001.

${ }^{39}$ Zob. E. B a r b o n i: Skauting a pedagogia wiary. Sandomierz 1998 s. $25 \mathrm{nn}$. 